\title{
Oksidatif Stres ve Antioksidanların İ̧̧ Sağlığına Etkileri
}

\author{
Effects of Oxidative Stress and Antioxidants on Occupational Health
}

\author{
Mete Han ÜNER (D) , ilkay YILMAZ
}

\begin{abstract}
ÖZET
Oksidatif stres, reaktif oksijen türlerinin (ROS), antioksidan koruyucu etki kapasitesini geçmesi sonucu ortaya çıkan bir durumdur. Antioksidan sistemlerin yetersiz geldiği durumlarda DNA, lipit ve protein yapılar zarar görmekte bu durum kanser, kardiyovasküler ve nerodejeneratif hastalıkların ortaya çıkış sürecini hızlandırmaktadır. İşçiler bulundukları ortam sebebiyle oksidatif strese maruz kalmaktadırlar. Ağır metallere, iyonize radyasyona, yüksek basınca ve titreşime maruz kalmak oksidatif stresin artmasına neden olmaktadır. Özellikle, ağır ve tehlikeli iş kollarında çalışanların diyetlerinin, işçi sağlığının korunması amacıyla A, E, C vitaminleri ve çeşitli antioksidan bileşiklerden zengin olması büyük önem arz etmektedir. Bu derlemede çeșitli iş kollarında çalıșan işçilerin oksidatif strese maruz kalmaları ve antioksidan bileşiklerin oksidatif stresi engellemedeki etkileri ile ilgili yayınlar derlenmiştir.

Anahtar Kelimeler: İşçi beslenmesi, iş sağlığı, oksidatif stres, reaktif oksijen, antioksidanlar.
\end{abstract}

\section{ABSTRACT}

Oxidative stress is a condition that occurs when reactive oxygen species (ROS) exceed their antioxidant prosective effect capacity. DNA, lipid and protein structures are damaged, when antioxidant systems are inadequate, and this speeds up the rate of cancer, cardiovascular and neurodegenerative diseases.Workers are exposed to oxidative stress due to their environment. Exposure to heavy metals, ionizing radiation, high pressure and vibration causes increased oxidative stress. It is of great importance that the diets of those working in heavy and dangerous business are rich in vitamins $\mathrm{A}, \mathrm{E}, \mathrm{C}$ and various antioxidant compounds in order to protect worker health. In this review, the exposure of oxidative stress to workers working in various business lines and the effects of antioxidant compounds on preventing oxidative stress were literature information has been compiled.

Keywords: Worker nutrition, occupational health, oxidative stress, reactive oxygen, antioxidants.

Mete Han ÜNER | metehanuner@gmail.com

Düzce Üniversitesi, Gölyaka Meslek Yüksekokulu, Düzce, Türkiye

Duzce University, Gölyaka Vocational School, Duzce, Turkey

ilkay YILMAZ | ilkayyilmaz@baskent.edu.tr | Sorumlu Yazar/Corresponding Author Başkent Üniversitesi, Güzel Sanatlar, Tasarım ve Mimarlık Fakültesi, Ankara, Türkiye Baskent University, Faculty of Fine Arts, Design and Architecture, Ankara, Turkey 


\section{GIIRIŞ}

Oksidatif stres, üretilen serbest radikallerle antioksidan savunma sistemi arasındaki dengenin bozulması şeklinde tanımlanır [1]. Serbest radikallerin oksijen kaynaklı olanlarına reaktif oksijen türleri (ROS) denir ve bunlara ait zararlı etkilerin yok edilmesinde vücut antioksidan savunma mekanizmaları genellikle yetersiz kalmaktadır. Mitokondride gerçekleşen metabolizma, yaşlanma, radyasyon, yüksek oksijen basıncı, kimyasallar ve inflamasyon sonucu yüksek reaktiviteye sahip ROS'lar üretilmektedirler. Bundan dolayı DNA, lipitler ve proteinler zarar görmekte, bu durum kanser, kardiyovasküler hastalıklar ve nörodejeneratif hastalıkların gelişimine katkı sağlamaktadır. Bu nedenle diyet kaynaklı antioksidanlar ortaya çıkabilecek hastalıklardan korunmada önemli olabilir [2,3,4]. Yine oksidatif stres, zihnimizin ve vücudumuzun yaşlanmasından, ateroskleroz, alzheimer, parkinson, kanser, diyabet ve psikolojik hastalıkların ortaya çıkmasına kadar birçok hastalıktan sorumludur $[5,6]$. Otoimmün hastalıkların gelişmesinde de en büyük etkenlerden biri serbest radikal artışına bağlı olarak oksidatif strestir. Oksidatif stres artışında, hücre komponenti hasara uğramakta, bağışıklık sistemi de hasarlı hücreye karşı antikor üreterek onu ortadan kaldırmaya çalışmaktadır, yani bağışıklık sistemi kendi hücrelerine saldırmakta$\operatorname{dir}[7]$.

Çalışılan iş kolu ile oksidatif stres arasında belirgin bir ilişki bulunmaktadır. [8]. Özellikle ağır ve tehlikeli iş kolları başta olmak üzere ihtiyaç duyulan besin öğeleri, sağlık, verimlilik, performans ve iş kazaları arasında anlamlı bir ilişki bulunmaktadır [9]. Çeşitli antioksidan özellikteki enzimler, mineraller, $\mathrm{E}$ ve $\mathrm{C}$ vitamini gibi bileşikler hücreleri oksidasyona karşı korumaktadırlar [10]. Bu sebeple dengeli beslenme ve yeterli antioksidan alımı önem kazanmaktadır.
Bu derlemede çeşitli iş kollarında çalışan işçilerin oksidatif strese maruz kalmaları ve antioksidan bileşiklerin sağlık üzerine etkileri ile ilgili literatür incelenmiştir.

\section{II. İŞÇILERDE OKSIDATIF STRESIN ETKILERI}

Serbest radikaller ve ROS, insan vücudundaki normal temel metabolik süreçlerde ortaya çıktığı gibi X-1şınları, ozon, sigara, toksik kimyasallar, radyasyon, ilaçlar, hava kirleticileri ve endüstriyel kimyasallara maruz kalma gibi dış kaynaklar sonucu da oluşabilmektedir. İnsanların yaptıkları işlerde maruz kaldıkları kimyasal madde, toz, gürültü ve ışınların işçilerin sağlıklarına olumsuz etki yaptığı, 19. yüzyıldan itibaren gözlenmiş ve önem kazanmaya başlamış$\operatorname{tir}[11]$.

Vücudumuz serbest radikalleri ve reaktif oksijen türlerini antoksidan sistemi ile yok etmektedir fakat oksidanların çok artması sonucu hücrelerde hasarlar meydana gelmektedir. Hasarlı hücreler onarılmadan bırakılırsa, bu durum birçok hastalık durumunda önemli bir rol oynamaktadır [12].

İşçilerin çalışma ortamına bağlı olarak değişmekle birlikte çalışma ortamı havası genellikle potansiyel oluşturabilecek tehlikeli kimyasalların bulunduğu ortamdır. Metal dumanlarına mesleki maruziyet, birçok mesleki ortamda rutin olarak gerçekleşir. Ayrıca mesleki ortamlarda işçiler yüksek dozlarda pestisitlere de maruz kalmaktadır. Bu maddeler vücut tarafından solunduğunda ve emildiğinde sağlık riski oluşturmaktadır. Bu durum vücudun proksidan / antioksidan dengesini de bozmaktadır [13]. İşçilerde ağır metallere mesleki ve çevresel maruziyet genellikle kadmiyum, cıva, nikel ve kurşun gibi maddelerin toksik etkileri nedeniyle sağlık tehlikelerine neden olması ile oluşur. Metaller oksidatif hasara neden olma potansiyeline sahiptir ve eritrositler dahil çeşitli hücre ve dokulara zarar verirler [14]. Çalışmalar sadece toksik maddelere maruz kalmanın 
değil, basınç, titreşim, radyasyon gibi etkilerin de önemli olduğunu göstermektedir. Fabrikalarda çalışan işçilerdeki oksidatif stres parametrelerinin tespiti için; kan ve spot idrar örneklerinden antioksidan enzimler, lipit peroksidasyon ürünleri olan plazma, eritrosit ve oksidatif DNA hasarı göstergelerine bakılabilmektedir [15].

\section{A. Oksidatif Stresin İşçi Sağlığına Etkileri Üzerine Ya- pılan Çalışmalar}

Enerji santrali çalışanları üzerine çift kör randomize kontrollü yapılan bir klinik çalışma sonucu, E ve C vitamini alımlarının lipit peroksidasyonu azalttığı bildirilmiştir. Yine $\mathrm{E}$ ve $\mathrm{C}$ vitamini alımının, son derece düşük elektromanyetik alanlara maruz kalmayla dahi düşüş eğilimi gösteren antioksidan enzimlerin seviyelerini arttırdığı gözlemlenmiştir [16].

Reaktif oksijen türlerindeki artış kanser, kardiyovasküler hastalıklar, multiple sklerozis, down sendromu, katarakt ve tümör oluşumu gibi birçok dejeneratif rahatsılıklara indirekt ya da direkt neden olabilir. Antioksidanların, hücreleri serbest radikal yapilardan ROS'un potansiyel zarar verici etkilerinden koruyucu bir role sahip olduğu bilinmektedir. [17, 18]. Normal şartlarda düşük oranlarda üretilen ve organizmaya zarar vermeyen serbest radikaler, iyonize radyasyona maruziyet, ağır metallerin vücutta birikmesi ve çevre kirliliği gibi durumlarda yüksek miktarlarda üretilmekte, dolayısıyla da oksidatif strese neden olmaktadır [19,20]. Düşük doz radyasyona maruz kalan hastane çalışanları üzerinde yapılan bir araştırmaya göre, kronik düşük doz radyasyonun, oksidatif stres ve kromozal hasarı indüklemesine bağlı olarak insanlarda zararlı etkilere neden olabileceğini belirtmektedir [21].

Kadmiyum ile tedavi edilen fareler üzerinde yapılan bir çalışmada, alyuvar sayısında, hemoglobin konsantrasyonunda ve hematokrit değerinde önemli ölçüde azalma göz- lemlenmiş̧ir [22].

Çin'de 2011-2013 yılları arasında 26.008 erkek işçi üzerinde yapılan bir araşıırmada ağır metallere maruz kalma ve alkol alma durumunun diyabet gelişimiyle ilişki içerisinde olduğu saptanmıştır [23]. Başka bir çalışsmada pnömokonyozu olan kömür madeni işçilerinde kırmızı kan hücreleri önemli ölçüde azalmıştır. Ayrıca antioksidan sisteme ait süperoksit dismutaz, katalaz, glutatyon peroksidaz gibi çeşitli enzimler hastalık durumuyla ilişkili bulunmuştur [24]. Metal fabrikasında yapılan bir çalışmaya göre iş̧ilerde metal raf üretim fabrikasında çalışan işçiler kontrol grubuna göre serbest radikallerin zararlı etkilerine daha fazla maruz kalmaktadırlar [15].

Sıçanların antioksidan durumları üzerinde melatonin ve radyasyonun etkisini inceleyen bir çalışmada melatoninin belirgin bir antioksidan koruma sağladığı gözlemlenmiştir [25]. Karanlık varlığında salgılanan bir hormon olan melatonin, lipofilik [yağda çözünme] özelliği nedeniyle bilinen en güçlü antioksidanlardandır. Lipofilik özelliği nedeniyle tüm vücut dokularına ulaşabilme kabiliyetine sahiptir [26]. İdrar ile 6-sülfatoksimelatonin atılımının serumdaki melatonin oranıyla yakın ilişkili bulunmuştur. Yine gece vardiyalarında çalışan işçilerde fazda kayma olsa dahi melatonin salınımı ile gece uykunun gelme zamanı arasındaki ilişkinin kaybolmadığı bildirilmiştir [27]. Araştırmalar, melatoninin antikanserojenik etkisini ortaya koymaktadır [28].

Vardiyalı çalş̧ma uyku bozukluğu olan işçilerde gastrointestinal ve kardiyovasküler hastalıkların artmasına ek olarak güvenliğe yönelik risklerde bulunmaktadır. Normal uyku zamanlarında çalışma, aşırı uyku hali ya da uykusuzluk iş performansında düşüş, azalan dikkat nedeniyle artan iş kazalarıyla ilişkilidir [29]. Gece vardiyalarında çalışan işçiler için gece uyanık kalabilmek ve dikkatin sürdürülebil- 
mesi önemli sorunlardır. Çalışmaya başlamadan önce 1-2 saat kadar kısa süreli uykunun, uyanıklıkta ve performansta artışı bir miktar iyileştirebileceği bildirilmiştir [30].

Organofosfat ve piretroid pestisitlere maruz kalan işçiler üzerine yapılan bir çalışma sonucu pestisitlere maruz kalan işçilerde DNA hasarının önlenmesi amacıyla antioksidan enzimlerin önemli rol oynadığı vurgulanmıştır [31].

Düşük serum magnezyum seviyeleri kurşun nedeniyle indüklenen oksidatif strese katkıda bulunmaktadır. Kurşun maruziyeti altındaki işçilerde magnezyum eksikliğinin önlenmesinin faydalı koruyucu etkileri bulunmaktadır [32]. Başka bir çalışmada, flavonoid luteolin [LUT] alımının, kurşun asetatın [PbAc] neden olduğu karaciğer hasarının azaltılmasında etkili olduğu bildirilmiştir. Luteolinin bu koruyucu etkisinin antienflamatuvar, antioksidan ve antiapoptotik özelliklerinden kaynaklandığı düşünülmektedir [33]. Kurşun maruziyetinin olası zararlı etkilerini inceleyen bir araştırmada ise yüksek kurşun seviyelerinin, düşük çinko seviyeleriyle ilişki içerisinde olduğunu gösterilmiştir. DNA hasarı ve kurşun maruziyetinden kaynaklı oksidatif stres üzerinde etkisi olan çinko seviyelerinden dolayı kurşun emiliminin büyük oranda azaldığı saptanmıştır [34].

Sıçanlarda, flubendiamid ve bakırın sito-genotoksisite ve oksidatif stres ile ilişkisi üzerine yapılan bir araştırmada; test edilen 4 anti oksidan bileşiğin [resveratrol, kateşin, kurkumin ve $\alpha$-tokoferol] siçan splenosit hücrelerinde flubendiamid ve bakır kaynaklı sitotoksik etkileri azalttığı rapor edilmiştir. Ayrıca $\alpha$-tokoferolün, oksidatif strese bağlı biyobelirteçleri düzelttiği ve dalaktaki histomimari lezyonları önlemede etkin olduğu bildirilmiştir [35].

Deney farelerinde yapılan bir araştırma, kronik gürültüye maruz kalmanın [tepe ses seviyesi 85 ve ortalama ses seviyesi $72 \mathrm{~dB}$ ] farelerde oksidatif DNA hasarına neden olduğu ortaya koyulmuş, bu potansiyel mutojenik lezyon- ların kanser ilerlemesine katkıda bulunabileceğine dikkat çekilmiştir [36].

Hiperbarik atmosfere maruziyet, solunum hava basınc1nın deniz seviyesindeki basınçtan, en az \% 10 daha fazla olduğu ortamlarda faaliyet gösterilen işlerde ortaya çıkmaktadır. Artan hava basıncı ROS ile reaktif azot türlerinin [RNS] ortaya çıkışını tetiklerken, antioksidanların tüketimini ve antioksidan aktivitede azalmaya neden olmakta, bununla beraber lipit peroksidasyonuna, DNA ve RNA'da hasarlanmayla ilişkili görülmektedir [37].

Uzunluğa bağlı olarak titreşim rejenerasyonu veya disfonksiyonu ve apoptozu, inflamasyonu ve reaktif oksijen türlerindeki artışı tetiklemektedir. Sıçanlar üzerinde yapılan bir çalışmada $125 \mathrm{~Hz}$ de 10 günlük titreşim maruziyeti altında kalan sıçanlarda ventral kuyruk arterlerinde daralma, mitokondriyel sayısında ve ROS yoğunluğunda artış gözlemlenmiştir. $250 \mathrm{~Hz}$ titreşime maruz bırakılan küçük sinirler ile mitokondri sayılarında azalma bildirilmiştir. Sonuçlara dayanarak, mitokondri sayısı ve aktivitesinin titreşimlerden etkilendiği sonucuna varılmıştır [38].

Dizel partikülü maddelere ve çevresel benzine maruziyetin benzin istasyonu çalışanlarında oksidatif stres ve bağşıklık sisteminde dengesizliklere neden olabileceğinin düşünüldüğü bir çalışmada, omega-3 yağ asitleriyle desteklenen çalışanların interferon-y (IFN-y) ve interlökin-17 ,(IL-17) konsantrasyonları, plesebo grubuna göre anlamlı olarak daha düşük bulunmuştur [39]. Yapılan bir deneyde E vitamini alımının yedi hafta boyunca içme suyu vasıtasıyla ağır metallere $(\mathrm{Pb}, \mathrm{Hg}, \mathrm{Cd}, \mathrm{Cu})$ maruz birakılan farelerin testis ve böbreklerinde koruyu etki gösterdiği gözlemlenmiştir. Veriler, E vitamini alımının ağır metallerin neden olduğu böbrek ve testiküler oksidatif yaralanmalarına karşı koruyucu olduğunu göstermektedir [40].

Yakıt ikmalinde çalışan benzin işçileri üzerinde yapılan 
bir çalışmada, benzindeki aromatik bileşiklere [özelliklede benzen, toulen, etil benzen ve ksilen] maruz kalmanın antioksidan enzim aktiviteleri ve eser metalerin $(\mathrm{Cu}, \mathrm{Zn}, \mathrm{Fe}$ ve $\mathrm{Mn})$ seviyelerini düşürdüğü saptanmıştır. Korunma amacıyla uygun Kişisel Koruyucu Donanım (KKD) kulanımı önerilmekte olup, eser metallere ve antioksidanlara olan ihtiyacı değerlendirilebilecek çalışmalara ihtiyaç duyulduğu belirtilmiştir [41].

Bir araştırmada, oksidatif stresin etkilerini belirlemek için tükürükteki 8-hidroksiguanin (8-OHGua) biyobelirteç olarak kullanılmıştır. Bu yöntem aracılığı ile 541 Japon denekte yaşam tarzı ve tükürük 8-OHGua düzeyleri arasındaki ilişki analiz edilmiştir. Tükürük 8-OHGua düzeyleri sigara içen, aşırı viseral yağ düzeyine sahip olan, hipertansiyon hastası bireyler ile yaşlı kişilerde önemli ölçüde yüksek bulunmuştur. Yine tükürük 8-OHGua, orta derecede egzersiz yapan veya yakın zamanda yeşil çay-kahve tüketen kişilerde ise istatistiksel olarak anlamlı derecede düşük bulunmuştur. Oksidatif stresin zahmetsiz bir şekilde toplanarak in vaziv olmayan bir yöntemle ölçülebilmesinin yaşam tarzıyla ilişkili hastalıkların önlenebilmesinde yararlı bir biyobelirteç olabileceğini düşündürmektedir [8].

\section{ANTIOKSIDAN BILEŞIKLERIN İŞÇİ SAĞLIĞI ÜZERINE ETKILERI}

Reaktif oksijen türlerinin oluşumunu engellemek, bu maddelerin meydana getirdiği hasarları önlemek ve detoksifikasyonu sağlamak üzere vücutta görev yapan savunma sistemlerine "antioksidan savunma sistemleri" ya da "antioksidanlar" adı verilir [42]. Vücudun antioksidan dengesini sağlamak için yeterli ve dengeli beslenme çok önemlidir. Yetersiz ve dengesiz besin alımı nedeniyle vücudun savunma mekanizmaları etkilendiği zaman hastalık durumları oluşabilmektedir. Vücudumuz için gerekli olan ve dışarıdan alınan eksojen antioksidanlar ve kaynakları
Tablo 1'de verilmiştir [43].

Tablo 1: Eksojen Antioksidanlar ve Kaynakları [43]

EKSOJEN Antioksidanlar Diyet Kaynakları

\begin{tabular}{|c|c|}
\hline $\begin{array}{r}\text { C vitamini } \\
\text { [Ascorbic asit] }\end{array}$ & $\begin{array}{l}\text { Dolmalık biber, çilekler, kivi, } \\
\text { bürüksel lahanası, brokoli. }\end{array}$ \\
\hline $\begin{array}{r}\text { Vitamin E } \\
\text { [Tokoferol / Tokotrionoller] }\end{array}$ & $\begin{array}{l}\text { Sebze yağı ve türevleri, } \\
\text { fındık tohumları. }\end{array}$ \\
\hline $\begin{array}{r}\text { Karotenoidler, } \\
\text { (A vitamini öncülleri) } \\
\text { [ } \alpha \text { karoten, } \beta \text {, karoten] }\end{array}$ & $\begin{array}{l}\text { Portakal, kırmızı sebzeler ve } \\
\text { meyveler [havuçlar, domates, } \\
\text { kayısı, erik] ve yeşil yapraklı } \\
\text { sebzeler [ıspanak, süs lahanası]. }\end{array}$ \\
\hline $\begin{array}{r}\text { Polifenoller } \\
\text { [Flavoneller, flavanols, anto- } \\
\text { siyoninler, izo flavonlar, } \\
\text { fenolik asit. }\end{array}$ & $\begin{array}{l}\text { Meyveler [elmalar, ardıç, üzüm] } \\
\text { sebzeler [kereviz, lahana, soğan], } \\
\text { bakliyatlar [fasulye, soya fasulyesi], } \\
\text { fındık, şarap, çay, kahve, kakao. }\end{array}$ \\
\hline $\begin{array}{r}\text { İz elementler } \\
\text { [selenyum, çinko] }\end{array}$ & $\begin{array}{l}\text { Deniz ürünleri, et, } \\
\text { Kepekli tahıllar. }\end{array}$ \\
\hline
\end{tabular}

Antioksidan açısından zengin gıdaların alımının artması, antioksidan kapasitesini arttırmaktadır. Özellikle ağır ve tehlikeli iş kollarında çalışanların besin alımları, işçi sağlığının korunması amacıyla $\mathrm{A}, \mathrm{E}, \mathrm{C}$ vitaminleri ve çeşitli antioksidan bileşiklerden zengin olması büyük önem arz etmektedir [44].

Antioksidan açısından zengin bir diyetin, obezite, diyabet ve kardiyovasküler durumlar gibi beslenmeye bağlı metabolik hastalıkların insidansını azalttığı ve sağlıklı yaşlanmaya katkıda bulunduğu çeşitli çalışmalarda gösterilmiştir [45]. Ancak bireysel genetik farkllıkların, oksidatif strese karşı etki gösteren antioksidan savunma sistemlerini ve bununla ilişkili olarak hastalık gelişimini etkileyebileceği de bildirilmektedir [43]. Yeterli ve dengeli beslenme tarzı ve yeterli miktarlarda antioksidan bileşik alımı sayesinde serbest radikallerin sağlı üzerindeki istenmeyen etkilerini 
azaltmak mümkün olabilmektedir. Antioksidan bileşikler uzun yaşamın önemli bir savunma mekanizması olarak görülmekte ve önerilmektedir [46]. Tablo 2'de antioksidanların etki mekanizmaları detaylı bir şekilde açıklanmış$\operatorname{tir}[4]$.

Tablo 2: Antioksidanların etki mekanizmaları [4]

\begin{tabular}{|c|c|}
\hline Etki Adı & Etki Mekanizması \\
\hline Toparlayıcı Etki & $\begin{array}{l}\text { ROS'ları bağlayarak ya da daha güçsüz mole- } \\
\text { küllere çevirerek etki etmektedir. }\end{array}$ \\
\hline Baskılayıcı Etki & $\begin{array}{l}\text { ROS'lara bir hidrojenin eklenerek aktiflikleri- } \\
\text { ni azaltarak ya da durağanlaştırarak etki } \\
\text { ederler. Bazı vitamin yapılar ile flavonoidler } \\
\text { bu türde antioksidan bileşiklerdir. }\end{array}$ \\
\hline $\begin{array}{l}\text { Zincir Parçalayıcı } \\
\text { Etkiler }\end{array}$ & $\begin{array}{l}\text { ROS'ların zincir yapılarını parçalayıcı etki } \\
\text { gösterirler. Hemoglobin, seruloplazmin ve } \\
\text { mineraller zincirleri parçalayıcı etkiye sahip- } \\
\text { tirler }\end{array}$ \\
\hline Onarma Etkisi & $\begin{array}{l}\text { ROS'ların ortaya çıkardıkları hasarları onar- } \\
\text { ma etkisine sahiptir. }\end{array}$ \\
\hline $\begin{array}{l}\text { Kinaz Kayıpları } \\
\text { Önlemek }\end{array}$ & Oksidasyon tepkimelerini durdurur. \\
\hline Enzim Etkisi & $\begin{array}{l}\text { SOD [süperoksittransmutaz] benzeri antiok- } \\
\text { sidan enzimlerle, diyet antioksidanların } \\
\text { birleşme oranlarını çoğaltarak etki ederler. }\end{array}$ \\
\hline
\end{tabular}

Toksik maddelerle çalışılan iş kollarında ise işçilerin menüleri yeterli ve dengeli beslenme kurallarına ve çalışma koşullarına uygun hazırlanmalı ayrıca bu iş kollarında çalışanların günlük besin alımları A, E ve C vitaminleri kaynağı olan besinlerle desteklenmelidir [47]. İşçilerin antioksidan savunma sisteminin, üretilen reaktif oksijene karşı dengeyi sağlayabilmesi için yeterli miktarda antioksidan alması gereklidir [48]. Yine kurşun, kadmiyum gibi çeşitli ağır metallerin kullanıldığı iş kollarında (Madencilik, döküm işleri, akü geri dönüşüm tesisleri, kaynak işleri, boya ve pil sanayii vb.) çalışmakta olan işçilerin maruz kaldığı bu toksik etkiyi azaltmak için beslenmelerinin Fe囚, Ca mineralleriyle $\mathrm{C}$ ve $\mathrm{E}$ vitaminlerinden zengin olmasına dikkat edilmelidir [9]. Antioksidan vitaminler ROS donörleri ve alıcıları olarak etki gösterirken, minerallerin enzim aktiviteleri üzerinde etkili olduğu bildirilmiştir [4].

\section{SONUÇ}

Canlı metabolizmasında sürekli olarak oksidasyon olayları meydana gelmekte, özellikle işçilerin çalışma ortamına bağlı olarak dışarıdan aldığı reaktif oksijen maddeler bu oksidasyon olaylarını hızlandırmaktadır. Literatürde çok çeşitli işlerin nasıl oksidatif strese neden olarak insan sağlığını olumsuz etkilediğine dair araştırmalar bulunmaktadır. İşçilerin sağlı̆̆ı, icra ettikleri iş kolunun özeliklerine uygun bir şekilde yeterli ve dengeli beslenmelerinden gerekmektedir. Yeterli ve dengeli beslenme serbest radikallerin olumsuz etkilerini azaltmakta, kaliteli ve uzun yaşam için tavsiye edilmektedir. Oksidan kaynaklı hastalıklarda işçilerin çalıştığı iş koluna göre maruz kaldığı oksidatif stres belirlenmeli ve uzmanlar tarafindan antioksidanlarca yeterli bir beslenme planı oluşturulmalıdır. Özellikle ağır ve tehlikeli iş kollarında çalışanların diyetlerinin, işçi sağlığının korunması amacıyla A, E, C vitaminleri ve çeşitli antioksidan bileşikler açısından yeterli olması büyük önem arz etmektedir.

YAZAR KATKILARI: Tüm yazarlar makalenin kaynak tarama, yazma, düzenleme aşamalarına eşit oranda katkıda bulunmuşlardır. Yazarlar makalenin son halini okumuş ve onaylamıştır.

ÇıKar ÇATışması: Yazarlar herhangi bir çıkar çatışması olmadığını, makalede araştırma ve yayın etiğine uyulduğunu beyan ederler.

Finansal Destek: Bu çalışmada herhangi bir kişi, kurum veya kuruluştan finansal destek alınmamıştır.

Етік Коміте OnaYı: Deney ürünü ve insan örneği kullanılmadığından etik kurul oluru gerekmemiştir. 


\section{KAYNAKÇA}

[1] Zelzer, S., Wonisch, W., Rinnerhofer, S., Niedrist, T., Tatzber, F., Cvirn, G., Wultsch, G., Mangge, H. (2018). The workload of heavy workers is associated with increased low-grade inflammation, emotional and oxidative stress. Free Radical Biology and Medicine, 124, 577.

[2] Halliwell, B. (1996). Oxidative Stress, Nutrition and Health. Experimental Strategies for Optimization of Nutritional Antioxidant Intake in Humans. Free Radical Researche, 25 (1), 57-74.

[3] Johansen, J.S., Harris, A.K., Rychly, D. J., Ergül, A. (2005). Oxidative Stress and The Use of Antioxidans in Diabetes: Linking Basic Science to Clinical Practice. Cardiovascular Diabetology, 4 (1), 5.

[4] Opara, E. C. (2002). Oxidative Stress, Micronutrients, Diabetes Mellitus and Its Complications. The Journal of The Royal Society for The Promotion of Health, 122 (1), 28-34.

[5] Şenses, S. V., Özyazgan, S., Akkan, A. G. (1999). Serbest Oksijen Radikalleri - II: Antioksidan Vitaminler, Doğal Antioksidanlar ve Radikallerin Rol Oynadığı Durumlar. Türk Aile Hekimleri Dergisi, 3 (3-4), 53-61.

[6] Egbuna, C., Ifemeje, J. C. (2017). Oxidative Stress and Nutrition. Tropical Journal of Applied Natural Sciences, 2 (1), 110-116.

[7] Srivastava, S., Singh, D., Patel, S., \& Singh, M. R., (2017). Role of enzymatic free radical scavengers in management of oxidative stress in autoimmune disorders. International journal of biological macromolecules, 101, 502-517.

[8] Watanabe, S., Kawasaki, Y., Kawai, K. (2020). Salivary 8 -Hydroxyguanine as a Lifestyle-Related Oxidative Stress Biomarker in Workers. Journal of Clinical Biochemistry and Nutrition, 66 (1), 57-61.

[9] Tüber. (2016). Türkiye Beslenme Rehberi 2015. Ankara: T.C. Sağlık Bakanlığı.

[10] Altıner, A, Atalay, H., Bilal, T. (2017). Bir Antioksidan Olarak E Vitamini. Balıkesir Sağlık Bilimleri Dergisi, 6 (3), 149-157.

[11] Gökpınar, Ş., Koray, T., Akçiçek, E., Göksan, T., Durmaz, Y. (2006). Algal Antioksidanlar. Ege Üniversitesi Su Ürünleri Dergisi, 23 (1/1), 85-89.

[12] Dizdaroglu M, Jaruga P, Birincioglu M, Rodriguez H., (2009). Free radicalinduced damage to DNA: Mechanisms and measurement. Free Rad Biol Med 32: $1102-15$
[13] Yang W, Omaye ST., (2009).Air pollutants, oxidative stress and human health. Mutation Res 674: 4554.

[14] Gupta A, Shukla GS., (1997). Enzymatic antioxidants in erythrocytes following heavy metal exposure: Possible role in early diagnosis of poisoning. Bull Environ Contam Toxicol 58: 198-205.

[15] Polat N , Kılınç A , Yalçın S., (2015). Metal raf üretim fabrikasında çalışan işçilerde kan ve idrar oksidatif stres parametreleri. Marmara Medical Journal. 26 (1): 25-29.

[16] Hosseinabadi, M. B., Khanjani, N., Norouzi, P., Mirzaii, M., Biganeh, J., Nazarkhani, F. (2020). Investigating the effects of vitamins $\mathrm{E}$ and $\mathrm{C}$ on oxidative stress and hematological parameters among power plant workers: A double-blind randomized controlled clinical trial. Toxicology and Industrial Health, 36 (2), 99-109.

[17] Koca, N., Karadeniz, F. (2005). Gıdalardaki Doğal Antioksidan Bileşikler. Gıda, 30 (4), 229-236.

[18] Okcu, Z., Keleş, F. (2009). Kalp-Damar Hastalıkları ve Antioksidanlar. Atatürk Üniversitesi Ziraat Fakültesi Dergisi, 40 (1), 153-160.

[19] Sezer, K., Keskin, M., (2014). Serbest Oksijen Radikallerinin Hastalıkların Patogenezisindeki Rolü. 28 (1): $49-56$

[20] Katz, D., Mazor, D., Dvilansky, A., Meyerstein, N. (1996). Effect of radiation on red cell membrane and intracellular oxidative defense systems. Free radical research, 24 (3), 199-204.

[21] Gao, J., Dong, X., Liu, T., Zhang, L., Ao, L. (2020). Antioxidant status and cytogenetic damage in hospital workers occupationally exposed to low dose ionizing radiation. Mutation Research/Genetic Toxicology and Environmental Mutagenesis, 850-851, 503152.

[22] Ognjanovic, B. I., Pavlovic, S. Z., Maletic, S. D., Zikic, R. V., Stajn, A. S., Radojicic, R. M., Saicic, Z. S., Petrovic, V. M. (2003). Protective influence of vitamin $\mathrm{E}$ on antioxidant defense system in the blood of rats treated with cadmium. Physiological Research, 52 (5), 563-570.

[23] Yang, A. M., Hu, X. B., Liu, S., Cheng, N., Zhang, D. S., Li, J. S., Li, H. Y., Ren, X. W., Li, N., Sheng, X. P., Ding, J., Zheng, S., Wang, M. Z., Zeng, T. Z., Bai, N, Y. (2019). Occupational exposure to heavy metals, alcohol intake, and risk of type 2 diabetes and prediabetes among Chinese male workers. Chronic diseases and translational medicine, 5 (2), 97-104. 
[24] Engelen, J. J., Borm, P. J., Van Sprundel, M., Leenaerts, L. (1990). Blood Anti-Oxidant Parameters at Different Stages of Pneumoconiosis in Coal Workers. Environmental Health Perspectives, 84, 165-172.

[25] Oli冈nyk, E. V., Meshchyshen, I. F. (2004). Effect of melatonin and radiation on pro-and antioxidant state of the liver and blood of rats. Ukrains' kyi biokhimichnyi zhurnal (1999), 76 (5), 144-147.

[26] Özçelik, F., Erdem, M., Bolu, A., Gülsün, M. (2013). Melatonin: Genel Özellikleri ve Psikiyatrik Bozukluklardaki Rolü. Psikiyatride Güncel Yaklaşımlar, 5 (2), 179-203.

[27] Öztürk, L., Darıyerli, N. (2000). Melatonin ve Uyku Fizyolojisi. Türkiye Tıp Dergisi, 7 (2), 104-109.

[28] Salt, A., Çenesiz, M., Çenesiz, S. (2017). Melatonin, Etkileri ve Kullanım Alanları. Etlik Veteriner Mikrobiyoloji Dergisi, 28 (1), 7-12.

[29] Schwartz, J. R., Roth, T. (2006). Shift work sleep disorder. Drugs, 66 (18), 2357-2370.

[30] Walsh, J. K., Muehlbach, M. J., Schweitzer, P. K. (1995). Hyptonics and Cafeine as Countermeasures for Shiftwork-related Sleepiness and Sleep Disturubance. Journal of Sleep Researche, 4 (S2), 80-83.

[31] Zepeda-Arce, R., Rojas-García, A. E., BenitezTrinidad, A., Herrera-Moreno, J. F., Medina-Díaz, I. M., Barrón-Vivanco, B. S., Villegas, G. P., Hernandez, O., Solis Heredia, M. J., Bernal-Hernández, Y. Y. (2017). Oxidative stress and genetic damage among workers exposed primarily to organophosphate and pyrethroid pesticides. Environmental toxicology, 32 (6), 1754-1764.

[32] Wyparło-Wszelaki, M., Wąsik, M., Machoń-Grecka, A., Kasperczyk, A., Bellanti, F., Kasperczyk, S., \& Dobrakowski, M. (2020). Blood Magnesium Level and Selected Oxidative Stress Indices in LeadExposed Workers. Biological trace element research.

[33] Al Megrin, W. A., Alkhuriji, A. F., Yousef, A. O. S. Metwally, D. M., Habotta, O. A., Kassab, R. B., Abdel Moneim, A. E., El-Khadragy, M. F. (2020). Antagonistic Efficacy of Luteolin against Lead Acetate Exposure-Associated with Hepatotoxicity is Mediated via Antioxidant, Anti-Inflammatory, and AntiApoptotic Activities. Antioxidants, 9 (1), 10.

[34] Wani, A. L., Ansari, M. O., Ahmad, M. F., Parveen, N., Siddique, H. R., Shadab, G. H. A. (2019). Influence of zinc levels on the toxic manifestations of lead exposure among the occupationally exposed workers. Environmental Science and Pollution Research, 26 (32), 33541-33554.
[35] Mandil, R., Prakash, A., Rahal, A., Singh, S. P., Sharma, D., Kumar, R., Garg, S. K. (2020). In vitro and in vivo effects of flubendiamide and copper on cyto-genotoxicity, oxidative stress and spleen histology of rats and its modulation by resveratrol, catechin, curcumin and $\alpha$-tocopherol. BMC Pharmacology and Toxicology, 21 (1), 1-17.

[36] Kvandova, M., Filippou, K., Steven, S., Oelze, M., Kalinovic, S., Stamm, P., Frenis, K., Vujacic Mirski, K., Sakumi, K., Nakabeppu, Y., Bagheri Hosseinabadi, M., Dovinova, I., Epe, B., Münzel, T., Kröller Schön, S., Daiber, A. (2020). Environmental aircraft noise aggravates oxidative DNA damage, granulocyte oxidative burst and nitrate resistance in Ogg1-/mice. Free Radical Research, 1-13.

[37] Tranfo, G., Marchetti, E., Pigini, D., Miccheli, A., Spagnoli, M., Sciubba, F., Conta, G., Tomassini, A., Fattorini, L. (2020). Targeted and untargeted metabolomics applied to occupational exposure to hyperbaric atmosphere. Toxicology Letters. doi: 10.1016/ j.toxlet.2020.03.022.

[38] Krajnak, K., (2020). Frequency-Dependent Changes in Mitochondrial Number and Generation of Reactive Oxigen Species in a Rat Model of VibrationInduced Injury. Journal of Toxicology and Enviromental Health, 83 (1), 20-35.

[39] Barkhordari, S., Mirmosayyeb, O., Mansourian, M., Hosseininasab, F., Ramezani, S., Barzegar, M., Amin, M. M., Poursafa, P., Esmaeil, N., Kelishadi, R. (2020). Omega 3 Supplementation Can Regulate Inflammatory States in Gas Station Workers: A Double-Blind Placebo-Controlled Clinical Trial. Journal of Interferon \& Cytokine Research, 40 (5), 262-267.

[40] Al-Attar, A. M. (2011). Antioxidant effect of vitamin E treatment on some heavy metals-induced renal and testicular injuries in male mice. Saudi journal of biological sciences, 18 (1), 63-72.

[41] Rizk, A. A., Abd El Wahab, E. W., El Marakby, F. A., El Gazzar, R. M. (2020). Assessment of Oxidative Stress Among Refueling Workers in an Egyptian Setting. Enviromental Science and Pollution Research International, 27 (15), 18099-18108.

[42] Şener G, Yeğen Berrak Ç., (2009). İskemi Reperfüzyon Hasarı. Klinik Gelişim Dergisi. 22: 5-13.

[43] Da Costa, L. A., Badawi, A., El-Sohemy, A. (2012). Nutrigenetics and modulation of oxidative stress. Annals of Nutrition and Metabolism, 60 (Suppl. 3), 27-36.

[44] Koivisto AE, Olsen T, Paur I, (2019). Effects of antioxidant-rich foods on altitude-induced oxidative 
stress and inflammation in elite endurance athletes: A randomized controlled trial. PLoS One. 14(6)

[45] Da Silva MS, (2016). Rudkowska I. Novel functional foods for optimal oxidative status in healthy ageing. Maturitas. 93:100-107.

[46] Karabulut, H., Gülay, M. Ş. (2016). Antioksidanlar. Mehmet Akif Ersoy Üniversitesi Veteriner Fakültesi Dergisi, 1 (1), 65-76.

[47] Ergün, C. (2016). Antioksidan Vitaminler ve Bağışıklık Sistemi. Türkiye Klinikleri Beslenme ve DiyetetikÖzel Konular, 2 (2), 56-61.

[48] Baysal, A. Beslenme. (2009). Ankara: Hatiboğlu Yayıncilı. 